\title{
ELECTRONIC-WORD OF MOUTH AND PRODUCT QUALITY ON BUYING INTEREST THROUGH TRUST IN ONLINE SHOPS
}

\author{
Dikdik Harjadi \\ dikdik.harjadi@yahoo.com \\ Dadang Suhardi \\ Nur Ayisiyah \\ Faculty of Economics, Universitas Kuningan \\ Jl. Cut Nyak Dhien No.36 A, Cijoho, Kuningan, Jawa Barat 45513
}

received: 10/7/19; revised: 3/12/19; published: 31/12/19

\begin{abstract}
This research aims at investigating the influence of e-WOM and product quality on buying interest through the customers' trust. This research used a quantitative research design with survey method. This research employed descriptive and verification research methods. A path analysis was conducted to analyze the interval data in this research. The result of data analysis and hypothesis testing revealed that e-WOM and product quality had an influence on customers' trust in online shops, e-WOM had an influence on the customers' trust in online shops, product quality had an influence on customers' trust in online shops, while e-WOM, product quality, and the customers' trust had an influence on buying interests in online shops, e-WOM had an influence on buying interests in online shops, product quality had an influence on buying interests in online shops, and the customers' trust had an influence on buying interests in online shops.
\end{abstract}

Keywords: e-WOM; product quality; trust; buying interest

\section{INTRODUCTION}

The development of communication, media, and information technologies, and the infrastructure and global information have affected the activities in the industry or in the field of trading, government, social, and politics. In the economic field, the development of technology and information have changed the company's business activity from traditional sales and marketing systems to modern ways. The development of commercial network has been proven by the presence of internet in business world. Those two aspects combined and became an electronic-based business, or known as e-business. The development of Internet technology was rapid, and it has been one of the aspects that influenced most of the people lifestyle. The data presented by Indonesia Internet Service Provider Association (APJII) revealed that Internet users in Indonesia in 2016 have raised, compared to those in 1998 which were only 500,000 users.

The number of Indonesia e-commerce companies caused a tough competition to attract people to visit and purchase through their marketing sites. Business through online market sites in Indonesia developed rapidly. This phenomenon could be indicated through a lot of online based market sites, such as Tokopedia, OLX,
Lazada, etc. Some online market places in Indonesia are presented in the Table 1

Table 1 shows that there were top 10 consisting of four e-commerce and six marketplaces. Lazada led all e-commerce with 21.2 million unique audiences. While Tokopedia led marketplaces with 14.4 million unique audiences. The list of top 10 marketplaces were Lazada, Blibli, Tokopedia, Elevania, Matahari Mall, Shopee, Bukalapak, Zalora, Qoo10, and Blanja.

Many online shops developed in Indonesia indicated that the people had a high interest in online shopping. Online shopping developed as an interesting trend along with the Internet user's growth. The Internet shopping system does not only save time, but it also allows the customers to get the best offered price. Many conveniences in online shopping does not guarantee that there are not any difficulties or obstacles in online shopping.

In a report entitled "E-Commerce in Asia Bracing for Digital Disruption," issued in November 2016, DBS Group Research revealed that there were still many of the societies that did not believe in online shopping sites.

Fraud often occurs in online business world, so that the customers pay more attention to trust.In line with an article on Solopos.com (2016), they revealed that the reasons of some of Indonesian people are reluctant to 
shop online due to payment system and trust. Therefore, a high level of trust in online shopping can reduce uncertainty due to unknown shop owner, product quality, and system performance. Trust is defined as a behavioral intention resulted from general trust in online retailers, or special beliefs in competence, integrity and virtue (Henning-Thurau et. al., 2004; Awad and Ragowsky, 2008; Septiari, 2018). According to Vongurai et. al., (2018), trust is relevant with the customer's purchase which positively influence buying interest. The customers' product knowledge is only based on the written information without touching the product directly. Trust plays an important role in determining the prerequisites of online purchase intentions for successful trading (Li et. al., 2014). There are some factors influencing the customer's trust in increasing buying interest in online shop, for instances, when conducting an online transaction, it is assumed that the transferred money will not be lost, but it will be replied with the desired product, as displayed on the online shop. When it happens, the customer's trust will be built, and cause the customer's interest to do transaction in an online shop.

Buying interest is a part of customer's behavior in the future with the aims of maximizing the prediction on purchasing decision, which is really carried out by the customers. According to Schiffman et. al., (2007), interest is a psychological aspect, which has a significant influence on behavioral attitude. It was also a source of motivation to lead a person in performing an activity or action. In online shopping, a customer will pass a finding information stage to strengthen the intention to shop online. The information can be opinion from people who has used and taken advantage of the product. The opinion could contain their satisfaction or dissatisfaction on the product. Furthermore, the information could be evaluated by the customers, and used in purchasing decision making. The opinion searched by the customers through electronic media is known as an Electronic Word of Mouth. According to Hennig-Thurau et. al., (2004), E-WOM can be defined as positive or negative statements made by potential, actual, or ex-customers of a product or company through the Internet (Vongurai et. al., 2018; Litvin et. al., 2008). E-WOM is also defined as an information exchange process of a product, service or company with other parties (Rawat et. al., 2017; Shen et. al., 2012; Wu, 2017). E-WOM are always related to the customers' experience of consumed product or service. E-WOM communication could be performed by various methods, such as posting opinion, comment, and product review on weblog, discussion forum, websites, e-bulletin, and social media (Shidqi et. al., 2019; Danis et. al., 2017; Zheng \& Cong, 2017). When the message content of electronic word of mouth is honest, people willtake it as a pleasant thing, and it does not cause harm, encourage people to tell to the others, so that the message can influence the customers' buying interest (Sari et. al., 2017). The statements from other customers are usually more trusted than the promotion done by a company. Through e-WOM messages, the customers obtain information about the quality of a product or service. In addition, a message containing on e-WOM can reduce effectively the risks and uncertainties encountered by the customers when buying a product or service.

Product quality has a specification towards a product or service, which can cause the customers' satisfaction. Product quality is a customer's consideration for a product related to all of its excellences and advantages (Chinomona et. al., 2013). According to Kotler and Keller (2012), product quality is capability of the used product to perform its functions. The product capabilities include durability, reliability, accuracy, ease of operation and reparation, and other valuable attributes of the product. Quality has an important role, both in terms of customers' point of view who are free to choose, and in terms of producers' point of view who could pay attention to quality control, which is useful for sustaining and broadening product marketing. The better the product quality, the higher the buying interest of the product. Product quality has an important role in Electronic Word of Mouth. Therefore, if quality of the product could be impressed by the customers, e-WOM would be conducted well and influence the customers' buying interest.

Based on the aforementioned explanation, electronic word of mouth and product quality could affect the customers' trust, which can encourage buying interest towards purchasing in online shop. The trust gained can have an impact on the progress of an online shop. It is supported by Danis et. al. (2017) regarding the influence of electronic word of mouth on the customers' decision by using e-commerce, there was a significant influence of electronic word of mouth on the customers' buying interest. However, a research conducted by Tiltay (2014) revealed that E-WOM does not have any positive result, or does not influence the customers' buying interest. Based on the theoretical framework, the hypotheses of this research can be formulated as the followings: 1) e-WOM and product quality influenced the customers' trust, 2) e-WOM influenced the customers' trust positively, 3) product quality influenced the customers' trust positively, 4) e-WOM, product quality, and trust influenced buying interest, 5) e-WOM influenced buying interest positively, 6) product quality influenced buying interest positively, and 7) trust influenced buying interest positively.

\section{METHOD}

This research used a quantitative research design with survey method. This research employed descriptive and verification research methods. Variable Operationalization in this research was as the following: 
E-WOM $\left(\mathrm{X}_{1}\right)$ was a positive or negative statement from the previous customer about a product or company through the Internet (Hennig-Thurau, 2004). E-WOM $\left(\mathrm{X}_{1}\right)$ indicated by intensity, other customers' opinion (valance of opinion), and the gained information (content). Product quality $\left(\mathrm{X}_{2}\right)$ is a combination of the properties and characteristics, which determine how far the output can fulfill the customers' requirements or assess, how far the properties and characteristics fulfill the needs (Tjiptono, 2008:20). Product quality $\left(\mathrm{X}_{2}\right)$ indicators include product performance, reliability, additional singularity, service ability (product speed), aesthetics (beauty of the product), and perceived quality (Tjiptono, 2008:25). The customers' trust $\left(\mathrm{X}_{3}\right)$ is all customers' knowledge and conclusion about the objects, attributes, and advantages. Customers' trust indicators $\left(\mathrm{X}_{3}\right)$ are a trusted account, which can influence the customers' mind, reliable, and convincing. Buying interest (Y) occurs due to the external influences, namely the emergence of product need, product introduction, and information evaluation. Buying Interest $(\mathrm{Y})$ indicators consist of interest in finding information about the product, buying consideration, interest in trying, desire to know the product, and desire to have a product.

The population of this research were 8,999 students of private college in Kuningan Regency. This research conducted a proportional random sampling technique, which allowed the samples were taken based on the proportion of each private college. In this research, the sample size was determined using Slovin formula. Based on the calculation, the sample size, which would be taken in this research was as much as 383 respondents (Table 2).

The distributing questionnaires was used to collect the data. Data measurement used in this research was an interval scale with Agree-Disagree Scale technique, where there was scale 1 (strongly disagree) to 10 (strongly agree) for all variables.

To examine the ability and instrument trust level in measuring the variables, a validity and instrument reliability tests were employed, where all questions out of 20 questions were valid and reliable. While the data analysis employed in this research was a path analysis.

\section{RESULT}

The result of the classical assumption test obtained that the four examined variables were normally distributed in non-multicollinearity regression model. From the four data variables obtained, there were no heteroscedasticity problem, and autocorrelation in the regression model. From the 383 respondents consisted of: 220 females (57\%) and 163 males (43\%) The respondents consisted of 103 participants $(27 \%)$ who were in the age of $18-21,228$ participants $(60 \%)$ were in the age of $22-25$, and older than 25 were as much as 52 participants $(13 \%)$.
Based on the data processing and analysis, the description of e-WOM (Variable $\mathrm{X}_{1}$ ), product quality $\left(\mathrm{X}_{2}\right)$, trust $\left(\mathrm{X}_{3}\right)$, and buying interest $(\mathrm{Y})$ as presented in Table 3.

Based on the summary of the result of descriptive analysis, all variables were in medium criteria, which showed that the condition of each variable still needed improvements.

Based on the result of hypothesis 1 until 7 on sub structural equations 1 and 2, it was obtained an empirical path diagram for Y model as explained in Figure 1.

The influence of empirical causal between e-WOM $\left(\mathrm{X}_{1}\right)$ and product quality $\left(\mathrm{X}_{2}\right)$ variables ontrust $\left(\mathrm{X}_{3}\right)$ was described through the following sub structural equation 1 , namely:

$$
\mathrm{X}_{3}=0,46_{2} \mathrm{X}_{1}+0,346 \mathrm{X}_{2}+0,715 \mathrm{e}_{1}
$$

The influence of empirical causal between e-WOM $\left(\mathrm{X}_{1}\right)$ and product quality $\left(\mathrm{X}_{2}\right)$, and trust $\left(\mathrm{X}_{3}\right)$ on buying interest $(Y)$ were described through the following sub structural equation 2 , namely:

$$
\hat{\mathrm{Y}}=0.199 \mathrm{X}_{1}+0.220 \mathrm{X}_{2}+0.568 \mathrm{X}_{3}+0.512 \mathrm{e}_{2}
$$

The summary of Figure 1 could be presented in Table 4.

The amount of the indirect effect and the total effect were described as the following: (1) the total effect of $X_{1}$ to $X_{3}$ was $0.462,(2)$ the total effect of $X_{2}$ to $X_{3}$ was $0.346,(3)$ the indirect effect of $\mathrm{X}_{1}$ to $\mathrm{Y}$ through $\mathrm{X}_{3}=$ $(0.462) \times(0.568)$ was 0.262 . Thus, the total effect $=p$ $\mathrm{yX}_{1}+\mathrm{IE}=0.199+0.262=0.461$. (4) The indirect effect of $\mathrm{X}_{2}$ to $\mathrm{Y}$ through $\mathrm{X}_{3}=(0.346) \times(0.568)$ was 0.196 . Therefore, the total effect of equals $\mathrm{p} \mathrm{yX}_{2}+\mathrm{IE}=0.220$ +0.196 was $0.416,(5)$ the total effect of $X_{1}$ to $Y$ was 0.199 , (6) the total effect $X_{2}$ to $Y$ was 0.220 , (7) the total effect $\mathrm{X}_{3}$ to $\mathrm{Y}$ was 0.568 .

Figure 1 depicted (a) partially, e-WOM had a positive and significant effect on buying interest. The amount of the partial and direct influence of e-WOM on buying interest was 0.199 or $19.9 \%$. Thus, the level of buying interest was influenced by e-WOM $19.9 \%$, while the remaining $80.1 \%$ was explained by other factors outside the model. (b) Product quality partially had a positive and significant effect on buying interest. The amount of the partial and direct influence of product quality on buying interest was 0.220 or $22 \%$. It indicated that the level of buying interest was influenced by product quality by $22 \%$, while the remaining $78 \%$ was explained by other factors outside the model. (c) Trust partially had a positive and significant effect on buying interest. The amount of the partial and direct influence of confidence in buying interest was 0.568 or $56.8 \%$, meaning that the level of buying interest was influenced by confidence at $56.8 \%$, while the remaining $43.2 \%$ was explained by other factors outside the model. 


\section{DISCUSSION}

Recommendations from other customers were usually considered more trustworthy than promotional activities performed by the company, and could greatly influence the decisions of others to use (or avoid) a service. In fact, the greater the risk perceived by customers in buying a service, the more actively they searched for and relied on word of mouth (WOM) news to help them in decision making. Uninformed customers about a service were more dependent on e-WOM than customers, who already understood. The customers' knowledge was strongly associated with the discussion of customers' attitudes, because knowledge is customers' trust. Customer's trust or knowledge was related to a belief that a product had various attributes, and the benefits of these attributes. Thus, e-WOM as a source of information and contained various attributes regarding the quality of the product would determine consumer confidence. It was in line with Noori et. al. (2016); Suhaily and Darmoyo (2017); Chinomona et. al. (2013) which stated that trust could mediate the relationship between E-WOM and product quality with the customer's buying interest. It was confirmed by Berger(2014); Zheng \& Cong (2017); Danis et.al. (2017), which suggested that e-WOM and product quality played a major role in influencing customer's trust in purchasing products online.

E-WOM communication variable had a significant and positive influence on trust. It resembled Vongurai et.al. (2018); Wu (2017); and Septiari (2018), which stated that e-WOM communication that occurred between customers was going well, information delivered by between customers led to positive information and in accordance with the customers' expectations after making a purchase, meaning that the customer's trust about information and service provided by the seller gave a positive influence on the customers. The occurrence of e-WOM was inseparable from the consumer experience of the product or service consumed. If the customers got satisfaction from their consumption experience, then consumers would voluntarily made statements (reviews) that they believed in the products offered. These results were in line with Septiari (2018), Shidqi et. al., (2019), Wu (2017) which revealed that e-WOM had a positive and significant influence on trust.

Product quality had a specification to goods or services which could lead to the customers' satisfaction. The better the product quality, the higher the consumer' trust in a product. The quality of a product could be fully impressed by consumers, so Word of Mouth would run well and it would have an impact and influence to the customers' trust. If the quality of products purchased by consumers was getting better, there would be a growing trust in the product. The results of this research indicate that a product quality had a positive and significant influenceon the customer's trust. The results of this research reinforced the results of research conducted by Suhaily and Darmoyo (2017), Septiari (2018), and Shen et. al., (2012) which also concluded that product quality had a positive and significant influenceon the customer's trust.

Supported by Awad and Ragowsky (2008), Noori, et. al., (2016), and Danis, et. al., (2017) in their research on the influence of electronic word of mouth, product quality, and trust in consumer purchasing behavior, it could be concluded that there was an influence significant between electronic word of mouth, product quality, and trust in the customer's buying interest. The higher the level of the customers' trust in an online shopping site, the higher the shopping interests of customers through the site. In conducting online transactions, trust was a strong factor that positively influenced online shopping interest.

In line with research conducted by Pradana (2016) which said that there was an influence of e-WOM on consumer buying interest. From these explanations it could be concluded that the electronic word of mount could influence trust that would encourage the customer's buying interest. The positive E-WOM results were an important method of gaining competitive advantage so as to encourage customer's buying interest. When the performed communication employed positive E-WOM, it would reinforce the confidence and buying interest of the customers.

In this research, it was found that product quality had a positive and significant influence on customer's buying interest. It meant that the higher the quality of the product being marketed, it would also increase the customer's buying interest. According to Septiari (2018) and Suhaily and Darmoyo (2017) who examined the influence of product quality on customers' buying interest, product quality was considered to be very important in building global marketing, whether a company was assessed based on the product. The product quality was influential in giving satisfaction and interest in the customer's purchasing. Thus, the results of this research resembled the two-research mentioned above.

The trust factor had a direct influence on the customer's buying interest. Trust became an important part of turning visitors into buyers. The main thing that a buyer considered when doing online shopping was whether, they trust a site that provided service facilities and trust the seller. Therefore, trust was an important factor in building and fostering long-term relationships with consumer buying interest. It was in line with the results of the research conducted by Chinomona et.al., (2013), Wu (2017), Danis, et.al. (2017). 


\section{CONCLUSION}

Based on the results of aforementioned data analysis, hypothesis testing, and the discussion, it can be concluded that E-WOM as a media of information about products had an influence on consumer confidence in purchasing products online. This indicated that if E-WOM was getting more massive and the quality of products described through its attributes would increase, it would also be able to increase consumer confidence in online stores. The trust built from the intensity of online communication of the products offered, so that it became viral based on the quality characteristics or high quality product attributes would encourage consumer interest to purchase these products in online stores. Therefore, increasing the customers' trust would have an impact on the customers' interest in purchasing at online stores.

This research examined the impact of e-WOM and product quality on trust and the impact on buying interest. There were some aspects that should be studied further, namely high buying interest needs to be followed up with a decision to make purchases at an online store. This is because interested customers are not yet guaranteed to make a purchase decision at an online store. Therefore there needs to be a more in-depth study of the further impact on consumer purchasing decision behavior. In addition, there are still many factors that build consumer confidence in on-line stores such as online store reputation, price, and service quality that have to be further investigated.

\section{REFERENCES}

Awad, N.F. and Ragowsky, A., 2008. Establishing trust in electronic commerce through online word of mouth: An examination across genders. Journal of Management Information Systems, 24(4), pp.101121.

Berger, J., 2014. Word of mouth and interpersonal communication: A review and directions for future research. Journal of consumer psychology, 24(4), pp.586-607.

Chinomona, R., Okoumba, L. and Pooe, D., 2013. The impact of product quality on perceived value, trust and students' intention to purchase electronic gadgets. Mediterranean Journal of Social Sciences, 4(14), p.463.

Danis T.C.E., Istiyanto. B., Ardyan. E. 2017. The Effect of Electronic Word of Mouth, Trust, Perceived Risk, and Site Quality on Transactions Using E-Commerce, International Conference "Sustainable Development Goals 2030 Challenges and Its Solutions.

Hennig-Thurau, T., Gwinner, K.P., Walsh, G. and Gremler, D.D., 2004. Electronic word-of-mouth via consumer-opinion platforms: what motivates consumers to articulate themselves on the internet? Journal of interactive marketing, 18(1), pp.38-52.

Kotler, P. and Keller, K., 2012. Dirección de marketing (Decimocuarta ed.). Naucalpan de Juárez: Pearson Education.

Li, H., Jiang, J. and Wu, M., 2014. The effects of trust assurances on consumers' initial online trust: A two-stage decision-making process perspective. International Journal of Information Management, 34(3), pp.395-405.

Litvin, S.W., Goldsmith, R.E. and Pan, B., 2008. Electronic word-of-mouth in hospitality and tourism management. Tourism management, 29(3), pp.458468.

Noori, A.S., Hashim, K.F. and Yusof, S.A.M., 2016. The Conceptual Relation of Electronic Word-of-mouth, Commitment and Trust in Influencing Continuous Usage of Social Commerce. International Review of Management and Marketing, 6(7S), pp.226-230.

Pradana, R.D.P.F.D., 2016. Electronic Word Of Mouth (E-WOM), Kepuasan Konsumen Dan Pengaruh Langsung Dan Tak Langsung Terhadap Minat Beli Konsumen (Studi Pada Mahasiswa FEB Untag Di Semarang). Media Ekonomi dan Manajemen, 30(1).

Rawat, K., Kumar, R. and Rawat, V.S., 2017, Electronic Word of Mouth Communication, IJARIIE Vol.3., pp.1-5.

Sari, N., Saputra, M. and Husein, J., 2017. Pengaruh electronic word of mouth terhadap keputusan pembelian pada toko online Bukalapak. com. Jurnal Manajemen Magister Darmajaya, 3(01), pp.96-106.

Septiari, E.D., 2018. The Effect of eWOM as Mediation of Website Quality and Trust.

Schiffman, L.G., Kanuk, L.L. and Wisenblit, J., 2007. Consumer behavior. Upper Saddle River, NJ.

Shen, Y., Li, S. and DeMoss, M., 2012. The effect of quantitative electronic word of mouth on consumer perceived product quality. International Journal of Management and Marketing Research, 5(2), pp.19-29.

Shidqi.H., Noor.Y.L., Kirbrandoko,. 2019. The Effect of Electronic Word of Mouth on Online Trust and Purchase Intention Among Millenials Generation on Instagram, RJOAS, 1 (85) January.

Suhaily, L. and Darmoyo, S., 2017. Effect of product quality, perceived price and brand image on purchase decision mediated by customer trust (study on japanese brand electronic product). Jurnal Manajemen, 21(2), pp.179-194.

Tjiptono, F., 2008. Service management mewujudkan layanan prima. Yogyakarta: Andi.

Tiltay, M. A. 2014. The Effect of Electronic Word of Mouth on Brand Image and Purchase Intention : An Application Concerning Cell Phone Brands For Youth Consumers in Turkey Eskisehir Osmaganzi University of Nevada, 8(2), 61-68.

Vongurai, R., Elango, D., Phothikitti, K. and 
Dhanasomboon, U., 2018. Social Media Usage, Electronic Word of Mouth and Trust Influence Purchase-Decision Involvement in Using Traveling Services. Asia Pacific Journal of Multidisciplinary Research, 6(4), pp.32-37.

Wu, M.S.F., 2017. A study on the effects of word-of- mouth on brand trust in tourism industry. Eurasia J. Math. Sci Technol. Ed, 13, pp.7995-8002.

Zheng. Y., Cong. Y., 2017. A Literature Review of The Infulence of Electronic Word of Mouth on Consumer Purchase Intention, Open Journal of Business and Management, Vol.5, pp.543-549.

Table 1. Indonesia's Biggest Online Market Places in 2017

\begin{tabular}{|c|c|c|c|c|c|c|c|}
\hline & & $\begin{array}{c}\text { Total Digital } \\
\text { Population }(000)\end{array}$ & Mobile (000) & Desktop (000) & $\begin{array}{l}\text { Total Minutes } \\
\text { (MM) }\end{array}$ & $\begin{array}{l}\text { Total Views } \\
\text { (MM) }\end{array}$ & $\begin{array}{c}\text { Average Minutes } \\
\text { per View }\end{array}$ \\
\hline 1 & Lazada.co.id & 21,235 & 15,864 & 8,107 & 526 & 552 & 1 \\
\hline 2 & Blibli.com & 15,556 & 13,837 & 2,651 & 635 & 422 & 1.5 \\
\hline 3 & Tokopedia.com & 14,401 & 13,006 & 2,217 & 1,548 & 326 & 4.7 \\
\hline 4 & Elevenia.co.id & 12,872 & 9,535 & 5,130 & 438 & 285 & 1.5 \\
\hline 5 & MatahariMall.com & 12,520 & 11,516 & 1,879 & 410 & 516 & 0.8 \\
\hline 6 & Shopee.co.id & 11,301 & 10,872 & 763 & 2,169 & 136 & 16 \\
\hline 7 & Bukalapak.com & 10,407 & 8,971 & 2,203 & 459 & 193 & 2.4 \\
\hline 8 & Zalora.co.id & 9,052 & 8,636 & 813 & 396 & 493 & 0.8 \\
\hline 9 & Qoo10.co.id & 7,689 & 7,641 & 123 & 76 & 91 & 0.8 \\
\hline 10 & Blanja.com & 5,823 & 5,673 & 327 & 81 & 88 & 0.9 \\
\hline
\end{tabular}

Source: http/www.ilmuonedata.com

Table 2. Table of Population Proportion and Sample

\begin{tabular}{clcrc}
\hline No & Name of Private Colleges & Population & Proportion & Sample \\
\hline 1 & Universitas Kuningan & 5,038 & 214.41 & 214 \\
2 & STIKes Kuningan & 1,389 & 59.17 & 59 \\
3 & Univesitas Islam Al-ihya & 1,232 & 53.43 & 53 \\
& Kuningan & & & \\
4 & STKIP Muhammadiyah & 1,184 & 50.39 & 51 \\
& Kuningan & & & \\
5 & Akademi Farmasi & 156 & 6.64 & 7 \\
& Muhammadiyah Kuningan & & & \\
\hline & Total & 8.999 & 383 & 383 \\
\hline
\end{tabular}

Table 3. Summary of the Result of Descriptive Analysis

\begin{tabular}{lcl}
\hline \multicolumn{1}{c}{ Variable } & Percentage & Criteria \\
\hline E-WOM $\left(\mathrm{X}_{1}\right)$ & $62 \%$ & Medium \\
Product Quality $\left(\mathrm{X}_{2}\right)$ & $62 \%$ & Medium \\
Trust $\left(\mathrm{X}_{3}\right)$ & $63 \%$ & Medium \\
Buying Interest $(\mathrm{Y})$ & $65 \%$ & Medium \\
\hline
\end{tabular}

Table 4. Result of Path Analysis

\begin{tabular}{lcccc}
\hline \multicolumn{1}{c}{ Model } & Path Coefficient & $\mathrm{t}$ & $\mathrm{p}$ & $\mathrm{R}^{2}$ \\
\hline \multicolumn{4}{l}{ Sub Structure 1 $\left(\mathrm{X}_{1}, \mathrm{X}_{2}\right.$ to $\left.\mathrm{Y}\right)$} \\
\hline $\mathrm{X}_{1}\left(\mathrm{p} \mathrm{X}_{3} \mathrm{X}_{1}\right)$ & 0.462 & 4.415 & 0.000 & 0.488 \\
$\mathrm{X}_{2}\left(\mathrm{p} \mathrm{X}_{3} \mathrm{X}_{2}\right)$ & 0.346 & 3.305 & 0.000 & \\
\hline \multicolumn{4}{l}{ Sub Structure $2\left(\mathrm{X}_{1}, \mathrm{X}_{2}, \mathrm{X}_{3}\right.$ to $\left.\mathrm{Y}\right)$} \\
\hline $\mathrm{X}_{1}\left(\mathrm{p} \mathrm{yX}_{1}\right)$ & 0.199 & 2.557 & 0.013 & 0.738 \\
$\mathrm{X}_{2}\left(\mathrm{p} \mathrm{yX}_{2}\right)$ & 0.220 & 2.997 & 0.004 & \\
$\mathrm{X}_{3}\left(\mathrm{p} \mathrm{yX}_{3}\right)$ & 0.568 & 6.876 & 0.000 & \\
\hline
\end{tabular}

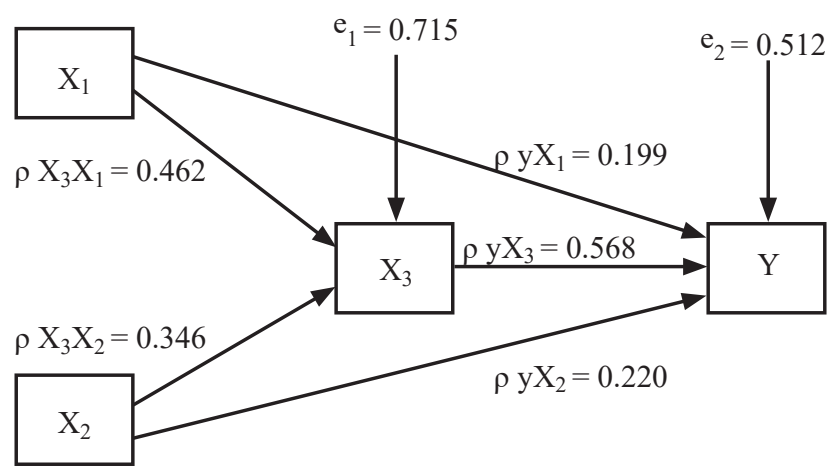

Figure 1. The Influence of Path Diagram of $X_{1}$ and $X_{2}$ on $Y$ through $X_{3}$ 